\title{
Research of the Export Rebates Mode for
}

\section{Production Enterprises}

\author{
Dazhu Yan \& Kexin Zheng \\ Changchun University of Science and Technology \\ Changchun 130022, China \\ E-mail: zhengkexin830@163.com
}

\begin{abstract}
The export rebates is a kind of tax policy usually used in the international trading to enhance the international competitive force of the export goods of native country. In 25 years' practice, through continual reform and perfection, the export rebates policy of China has exerted very important function to develop the foreign trade and increase the foreign exchange through exports for China. However, with the continual development of economy, the current export rebates mechanism still has some conflicts and problems. The deficiencies existing in the computation mode of "exemption, set off and refund" of export goods of current production enterprises are analyzed and discussed from the view of value added tax, and some improved suggestions are proposed from the tax basis to more scientifically and reasonably exert of the positive function of the export rebates policy in the international trading.
\end{abstract}

Keywords: Production enterprises, Export rebates, Exemption, Setoff and refund

\section{The actuality of the export rebates of China}

The export commodity tax refund (exemption) is a kind of taxation measure of refunding or exempting indirect tax (including value added tax and excise in China) which has been usually adopted in the international trading by many countries in the world to encourage the fair competition of the export commodities from various countries. The intention is to balance the taxation, and by collecting the zero tax rate to export products, the export products could be exported with the price exclusive of tax, and achieve the taxation condition with relatively equal competition comparing with the commodities in other countries or regions, and strengthen the international competitive force of the commodities of the native country. Its meaning is to promote the native country to develop the export-oriented economy, increase the export, and expand the export foreign exchange. The tax refund (exemption) of export products is a kind of international tradition, according with the basic principle of WTO.

The export commodity tax refund (exemption) of China means that the export commodities applying to customs in China will be refunded or exempted for the added value tax and the consumption tax which have been levied in various product and circulation parts in China according to the tax law in the international trading, i.e. the export commodities with the value added tax will be levied for zero tax rate, and the export commodities with the consumption tax will be exempted.

Since 1985, China begun to implement the export rebates policy, and based on the basic principle of "refunding what have been levied" and "refunding nothing what have not been levied and refunding tax to the core", China has founded a series of tax processing methods. The implementation and continual perfect of the export rebates policy will help China to strengthen the international competitive force of export commodities, expand the export, increase the employment, ensure the international balance of payments, and promote the sustainable, quick, and healthy development of national economy.

However, at the same time, though by continual reform and perfection, the current export rebates mechanism of China still has some conflicts and problems which should be solved urgently. On the one hand, because of the difference of the tax rate and the tax rebate rate, the tax could not be refunded to the core, i.e. the tax levied exceeds the tax refunded. On the other hand, because of the deficiencies of the current value added tax laws such as the deductions of the transportation charge and the imperfect taxation management, the tax dodging and cheating would occur time to time, and the tax refunded would exceed the tax levied. Therefore, the further reform and perfection of the export rebates system is the general trend. 
As viewed from the value added value, the deficiencies existing in the computation mode of "exemption, setoff, and refund" of export goods of current production enterprises are analyzed and discussed, and some improved suggestions are proposed from the tax basis to more scientifically and reasonably exert of the positive function of the export rebates policy in the international trading.

\section{Analysis of problems in the current export rebates mode}

In the "Measures for the Administration on Export Tax Refund (Exemption)", China regulated two kinds of tax rebates computation methods. The first one is the method of "exemption, set off and refund", and it is mainly applied in the production enterprises which export their own commodities by the self-support mode or the commission mode. The second one is the method of "refund after collection", and it is mainly applied in the foreign trade enterprises purchasing the goods for the export.

(1) According to the "Circular of the State Council Concerning Measures for Tax Exemption, Offset and Refund of Export Goods Managed by Production Enterprises or Agencies by Agreement (Trail)", the tax exemption, offset, refund amounts of export goods managed by production enterprise should be computed according to the FOB price and the tax rebate rate of export goods. The concrete computation formulas are described as follows.

a). The computation of the current tax payable amount

The current tax payable amount $=$ the VAT on sales of the current goods for home use - (the current VAT paid the current tax exemption, offset, refund amount excluding non-assessable and non-exempt amount) - the tax retained amount at the end of the prior period

If the current tax payable amount $>0$, the current tax payable amount $=$ the current VAT payable

If the current tax payable amount $<0$, the current tax payable amount $=$ the tax retained amount at the end of the current period

b). The computation of the current tax exemption, offset, refund amount

The current tax exemption, offset, refund amount $=$ the FOB price of export goods $\times$ the foreign exchange board rate of RMB $\times$ the tax rebate rate of export goods - the deductible amount of the tax exemption, offset, refund amount

The deductible amount of the tax exemption, offset, refund amount = the price of the raw materials of exemption $x$ the tax rebate rate of export goods

c). The computation of the current refundable tax amount and the current exemption and setoff tax amount

If the tax retained amount in the end of the current period $\leq$ the current tax exemption, setoff, and refund amount, so

The current refundable tax amount $=$ the tax retained at the end of the current period

The current exemption and setoff tax amount $=$ the current tax exemption, setoff, and refund amount - the current refundable tax amount

If the tax retained amount at the end of the current period > the current tax exemption, setoff, and refund amount, so

The current refundable tax amount $=$ the current tax exemption, setoff, and refund amount

The current tax exemption and setoff amount $=0$

d). The computation of the current tax exemption, setoff, and refund excluding non-assessable and non-exemption amount

The computation of the current tax exemption, setoff, and refund excluding non-assessable and non-exemption amount $=$ the current FOB price of export goods $\times$ the foreign exchange board rate of RMB $\times$ (the taxation rate of export goods - the tax rebate rate of export goods) - the deductible amount of the current tax exemption, setoff, and refund excluding non-assessable and non-exemption amount

The deductible amount of the current tax exemption, setoff, and refund excluding non-assessable and non-exemption amount $=$ the price of the raw materials of exemption $\times$ (the taxation rate of export goods - the tax rebate rate of export goods)

To simplify the problem, the price of the raw materials of tax exemption is not considered in this article.

(2) The VAT of export goods of foreign trade enterprises should be computed according to the input VAT and the tax rebate rate noted on the special VAT invoices of export and import goods. 
The refundable tax amount $=$ input amount of foreign trade purchase excluding VAT $\times$ the tax rebate rate

Above computation mode indicates that for the production enterprises which export their own goods and export the goods that they purchased, two different tax rebate modes are adopted, so different tax rebate results will occur.

For example, certain one production enterprise which exports its own products is the common taxpayer of VAT, and the taxation rate of export goods is $17 \%$, and the tax rebate rate is $13 \%$. In April of 2009, the businesses of the enterprise include purchasing a batch of raw materials, obtaining 2 million Yuan noted on the special invoices of VAT, purchasing goods with the credit input tax amount of 0.34 million Yuan (goods have entered into the warehouse), 30 thousands Yuan of the tax retained at the end of the prior period, 1 million Yuan of the sales amount of goods for home use in the current month, and 0.17 million Yuan of the VAT on sales.

Sales mode one: The sales amount of export goods in April is 2 million Yuan amounting to RMB. Compute the current tax exemption, setoff, and refund amount, the refundable tax amount, and the tax exemption and setoff amount.

The current tax exemption, setoff, and refund excluding non-assessable and non-exemption amount $=200 \times$ $(17 \%-13 \%)=8$ (ten thousands Yuan)

The VAT payable amount $=100 \times 17 \%-(34-8)-3=-12$ (ten thousands Yuan)

The tax exemption, setoff, and refund amount of export goods $=200 \times 13 \%=26$ (ten thousands Yuan)

The tax retained amount at the end of the current period (12 ten thousands Yuan) is less than the current tax exemption, setoff, and refund amount (26 ten thousands Yuan), so the current refundable tax amount equals to the tax retained amount at the end of the current period (12 ten thousand Yuan).

The current tax exemption and setoff amount $=26-12=14$ (ten thousand Yuan)

Sales mode two: In the former example, other conditions will not be changeable, suppose that the sales price of these export goods is 300 million Yuan amounting to RMB.

The current tax exemption, setoff, and refund excluding non-assessable and non-exemption amount $=300 \times$ $(17 \%-13 \%)=12$ (ten thousands Yuan)

The VAT payable amount $=100 \times 17 \%-(34-12)-3=-8$ (ten thousands Yuan)

The tax exemption, setoff, and refund amount of export goods $=300 \times 13 \%=39$ (ten thousands Yuan)

The tax retained amount at the end of the current period ( 8 ten thousands Yuan) is less than the current tax exemption, setoff, and refund amount (39 ten thousands Yuan), so the current refundable tax amount equals to the tax retained amount at the end of the current period ( 8 ten thousand Yuan).

The current tax exemption and setoff amount $=39-8=31$ (ten thousand Yuan)

Sales mode three: In the former example, other conditions will not be changeable, and the production enterprise sells the goods to certain one foreign trade enterprise by the price of 150 ten thousand Yuan (excluding tax), and this foreign trade enterprise exports these goods by the FOB price of 200 ten thousand Yuan. So,

The tax refundable amount $=150 \times 13 \%=19.5$ (ten thousand Yuan)

The tax non-refundable amount $=150 \times(17 \%-13 \%)=6$ (ten thousand Yuan)

In above cases, when other conditions will not be changeable, because of different sales mode and FOB prices, the tax rebate amounts of same goods will change. Formally, for production enterprises, when the FOB price increases, the tax exemption, setoff, and refund amount of export goods will increase also, but the tax exemption, setoff, and refund amount is only a quota of tax rebate, and the actual tax rebate amount decreases from 12 ten thousand Yuan to 8 ten thousand Yuan, and the difference (4 ten thousand Yuan) is counted into the cost of export goods. For foreign trade enterprise, the input tax amount which could not be exempted and counted into the cost of export goods is only 6 ten thousands. If the condition is further changed, supposing that the input tax amount which could be exempted of export goods is 44 ten thousand Yuan, the current repayable VAT amount is -22 ten thousand Yuan (i.e. $100 \times 17 \%-(44-8)-3$ ), and the current refundable tax amount equals to 22 ten thousand Yuan. But this result is not fair.

The essential of the conflict is that the computation formula of "exemption, setoff, and refund" of production enterprise conflicts with the original intention of the tax rebate policy. The tenet of tax rebate is to exempt and refund the VAT and the consumption tax of the export goods which have been levied in various production and circulation parts. According to that, the turnover tax amount burdened by the goods before they are exported 
should be computed when computing the tax rebate amount. In fact, the FOB price of export goods has not necessary quantity relation with the levied VAT input tax amount regulated in the domestic production and circulation parts. For the computation result of the current formula, on the one hand, as viewed from the computation of "the current tax exemption, setoff, and refund amount", the FOB price of export goods usually will exceed the sum of various purchasing prices in the prior period, and according to the current formula, the computed "current tax exemption, setoff, and refund amount" will exceed the tax amount levied in various parts before export when the setoff and refund amount and the different between the taxation and refund tax rates are not considered, so more tax amount will be refunded, and the country will undertake the economic loss. On the other hand, as viewed from the computation of "the current tax exemption, setoff, and refund excluding non-assessable and non-exemption amount", because it is computed according to the FOB price of export goods, the enterprise will finally levy more or less tax amount, and undertake economic loss. In addition, if the input tax amount of the enterprise because purchasing goods increases, the actual current tax rebate amount will increase, and though the total tax of the enterprise doesn't change, but with the change of the taxation time, certain influence will occur from the time value of currency. At the same time, between the production enterprise and the foreign trade enterprises, because of different tax rebate computation modes, even if same batch of goods is exported by same FOB price, its tax rebate amount and the refundable input amount are also different.

\section{Suggestions to perfect the export rebates mode of production enterprises}

To solve the conflict and problem existing in the current tax rebate computation mode of production enterprise, revert the original intention of the export rebate policy, balance the tax difference between the self-support export of production enterprise and the purchasing export of foreign trade enterprise, and the embody the taxation fairness, the export rebate computation method of foreign trade enterprise is suggested, and for the export of production enterprise, the actual cost of product should substitute the FOB price to compute the export rebate amount as the tax base. The computation of the input tax amount of the actual product cost could be confirmed by the actual product costs table waved by the production department of enterprise, and the example is seen in Table 1 .

Table 1 is the actual cost table of certain export product in Dec of 2009, and it lists various costs of the enterprise to produce this product in detail, where,

The total amount of raw materials consumed by unit product is 5376.10 Yuan;

The total amount of fuels consumed by unit product is 4681.06 Yuan;

The total amount of the discount of fixed asset is $297.21+9.18=306.39$ Yuan.

The input tax amount of each unit cost could be computed by above data, and supposing that the taxation rate of the refundable fixed asset of the raw materials of this batch of goods is $17 \%$, so

The VAT input tax amount of unit product $=(5376.10+4681.06+306.39) \times 17 \%=10363.55 \times 17 \%=1761.80$ Yuan

Supposing that the VAT rebate rate of these export goods is $13 \%$, so

The refundable tax amount $=10363.55 \times 13 \%=1347.26$ Yuan

The tax excluding non-assessable and non-exempt amount $=10363.55 \times(17 \%-13 \%)=414.54$ Yuan

By the computation, the refundable VAT amount of these good in the export part is 1347.26 Yuan, and the tax excluding non-assessable and non-exempt amount (414.54 Yuan) should be counted into the product sales cost. By this computation mode, whether these goods are exported by what price, its tax rebate amount will not change. At the same time, this method also could eliminate the influence of the current input tax amount and the export rebate amount induced by different goods purchasing times.

In fact, in recent years, to perfect the taxation system, China has adopted multiple measures such as the Golden Tax Project and Canceling the VAT preferential policy in the waste and old material industry. But the reform could not accomplish in an action, which needs multiple measures to perfect and support it together, and with the continual reform of the VAT law system and the continual strengthening of export rebate management, the export rebate policy of China will be perfect increasingly, and the zero tax rate of export goods will be realized finally, and the foreign trade of China will develop more healthily and orderly.

\section{References}

Decree of the Ministry of Finance and the State Administration of Taxation, No. 50. (2008). Detailed Rules fro the Implementation of the Provisional Regulations of the People's Republic of China on Value Added Tax. Dec. $18,2008$. 
Decree of the Ministry of Finance and the State Administration of Taxation, No. 157. (2008). Notice of the Ministry of Finance and the State Administration of Taxation on the VAT Polices on Renewable Resources of the Ministry of Finance. Dec. 9, 2008.

Decree of the State Administration of Taxation, No. 51. (2005). Notice of the State Administration of Taxation Issued a Circular on the Export Commodity Tax Refund (Exemption) Administration Measures (Trial). Mar. 16, 2005.

Decree of the State Administration of Taxation, No. 64. (2004). Notice of the State Administration of Taxation Issued Export Commodity Tax Refund (Exemption) Administration. May 31, 2004.

Decree of the State Council, No. 538. (2008). Provisional Regulations of the People's Republic of China on Value Added Tax. Nov. 10, 2008.

Table 1. Practical cost table of certain product in Dec of 2009

\begin{tabular}{|c|c|c|c|c|c|c|}
\hline \multirow{2}{*}{ Item } & \multirow{2}{*}{ Measurement unit } & \multicolumn{3}{|c|}{ Total costs } & \multicolumn{2}{|c|}{ Unite cost } \\
\hline & & Consumption & Unit price & Sum & Consumption & Sum \\
\hline Output (ton) & 23313.287 & & & & & \\
\hline 1. Raw materials & & & & $125,334,562.24$ & & $5,376.10$ \\
\hline a. Material A & ton & $45,157.837$ & $2,169.89$ & $97,987,610.32$ & 1.9370 & $4,203.08$ \\
\hline b. Material B & ton & 396.326 & $7,747.64$ & $3,070,593.03$ & 0.0170 & 131.71 \\
\hline c. Material C & ton & 303.073 & $2,929.23$ & $887,769.97$ & 0.0130 & 38.08 \\
\hline d. Material D & ton & 7.547 & $9,112.99$ & $68,774.20$ & 0.0003 & 2.95 \\
\hline e. Material E & ton & 7.497 & $2,083.39$ & $15,619.90$ & 0.0003 & 0.67 \\
\hline f. Material F & ton & $11,237.004$ & $2,261.99$ & $25,418,010.55$ & 0.4820 & $1,090.28$ \\
\hline 2. Fuels & & & & $109,130,895.24$ & 1.3381 & $4,681.06$ \\
\hline a. Electric power & Ten thousand KWH & $31,195.2925$ & $3,498.31$ & $109,130,895.24$ & 1.3381 & $4,681.06$ \\
\hline Where, technical power & Ten thousand KWH & $30,463.635$ & $3,498.31$ & $106,571,329.46$ & 0.0314 & $4,571.27$ \\
\hline Electrolysis electric power & Ten thousand KWH & 679.857 & $3,498.31$ & $2,378,353.17$ & 0.0292 & 102.02 \\
\hline Casting electric power & Ten thousand KWH & 51.800 & $3,498.31$ & $181,212.61$ & 0.0022 & 7.77 \\
\hline & & 731.657 & $3,498.31$ & $2,559,565.78$ & 0.0314 & 109.79 \\
\hline b. Compressed air & & & & & & \\
\hline 3. Salary and added fees & Yuan & & & $4,955,938.55$ & & 212.58 \\
\hline 4. Manufacturing charge & Yuan & & & $9,017,812.54$ & & 386.81 \\
\hline a. Direct charges & Yuan & & & & & - \\
\hline Where, salaries and welfare & Yuan & & & $175,319.15$ & & 7.52 \\
\hline Depreciations & Yuan & & & $6,928,880.33$ & & 297.21 \\
\hline Repair charge & Yuan & & & $3,336,051.16$ & & 143.10 \\
\hline Machine materials & Yuan & & & & & \\
\hline b. Assistant charges & Yuan & & & & & - \\
\hline Where, salaries and welfare & Yuan & & & $1,275,265.59$ & & 54.70 \\
\hline Depreciations & Yuan & & & $213,910.88$ & & 9.18 \\
\hline Repair charge & Yuan & & & $190,272.50$ & & 8.16 \\
\hline Machine materials & Yuan & & & & & - \\
\hline 5. Waste discharge return & & & & & & - \\
\hline Manufacturing cost & Yuan & & & $248,439,208.57$ & & $10,656.55$ \\
\hline
\end{tabular}

